\title{
Aplikasi Toko Online Ens Shop Berbasis Android Menggunakan Metode Cross Selling
}

\author{
D'jayus Noor Salim*1 , Is adora Nugroho $^{2}$, Oktaviana Putri Se tyanto ${ }^{3}$ \\ 1,2,3 Program Studi Sistem Informasi, STMIK AUB, Surakarta, Indonesia \\ e-mail: *1djayusnoor@stmik-aub.ac.id, ${ }^{2}$ isadora.nugroho@stmik-aub.ac.id
}

\begin{abstract}
Abstrak
Transaksi pemesanan barang pada ENS Shop masih cukup sederhana yaitu dengan menerima sejumlah pesanan melalui Whatsapp, BBM, dan pesan via Facebook. Saat ini yang menjadi permasalahan pada ENS Shop adalah kegiatan penjualan online YANG belum terintegrasi dengan baik dalam hal pemesanan, pembayaran dan pembuatan laporan. Dengan adanya Aplikasi Toko Online ENS Shop Berbasis Android Menggunakan Metode Cross Celling dapat memberikan solusi perbaikan sistem yang berjalan di ENS Shop menjadi lebih baik, efektifdan efisien.

Rancang bangun ini dirancang menggunakan metode Waterfall dengan struktur data (Data Flow Diagram), software yang digunakan adalah Apache Cordova menggunakan bahasa pemrograman HTML, PHP, dan Javascript serta MySQL sebagai databasenya. Aplikasi Toko Online ENS Shop Berbasis Android Menggunakan Metode Cross Celling dapat melakukan pemesanan dan penjualan produk ENS Shop, pembayaran melalui transfer rekening dan proses pembuatan laporan penjualan.
\end{abstract}

Kata kunci-Rancang bangun, Toko online, Metode Cross Celling

Abstract
Stuff ordering transaction in ENS Shop is still quite simple, by accepting some orders via Whatsapp, BBM, and Facebook. Nowadays, the activities of book, payment, and report become current problems in ENS Shop. The Online store application of ENS Shop Android-based by using Cross Celling method provides solutions in system reparation becomes better, effective, and efficient.

This architecture was designed by using Waterfall method with data structure (Data Flow Diagram) and Apache Cordova software (includes programs of: HTML, PHP, Javascript, and MYSQL as the database). Books and cells of ENS Shop products, transfer payments, and sales reports process can applied by the use of Online store application of ENS Shop Androidbased by using Cross Celling method.

Keywords-Architecture, Online shop, Cross Selling method

\section{PENDAHULUAN}

ENS Shop merupakan sebuah toko baju online yang berlokasi di Jalan Letjen Sutoyo No. 7 Kios Krapyak Sragen, toko ini menjual berbagai jenis pakaian seperti jilbab, baju, celana, rok, dan lain-lain. Selama beroperasi ENS Shop telah memasarkan produk ke beberapa daerah baik di pulau jawa maupun di luar pulau jawa.

Transaksi pemesanan barang pada ENS Shop cukup sederhana yaitu dengan memesan sejumlah barang melalui Whatsapp, BBM, dan Facebook. Pemesanan barang dikirim melalui 
inbox Facebook, BBM dan Whatsapp, kemudian permintaan barang pelanggan akan diperiksa terlebih dahulu oleh pemilik apakah masih tersedia atau tidak, jika stok habis maka pemilik akan memberitahukan kepada pemesan bahwa stok habis, jika stok tersedia maka dilanjutkan dengan pembayaran senilai barang yang dipesan ditambah dengan ongkos kirim sesuai alamat pemesan. Pembayaran dilakukan dengan cara transfer bank ke nomor rekening pemilik ENS Shop, apabila pembayaran tidak dilakukan dalam kurun waktu satu hari maka pemesanan dianggap batal.

Sistem penjualan pada toko online ENS Shop memiliki beberapa kelemahan yaitu pelanggan mengalami kesulitan untuk melihat semua katalog produk dari ENS Shop. Tidak semua produk yang dijual akan ditampilkan oleh pemilik ENS Shop karena ruang katalog foto yang terbatas dan belum terstruktur dengan baik. Sehingga pelanggan menanyakan satu persatu barang yang akan diminati. Pelanggan juga direpotkan dengan sistem pemesanan yang harus chatting dengan pemilik toko online dan menuliskan apa saja barang yang akan dipesan, selain itu pemilik ENS Shop juga sering kewalahan untuk melayani pemesan karena harus chating dengan banyak calon pembeli dan menanyakan secara detail barang yang dipesan. Hal ini membutuhkan waktu yang cukup lama untuk melayani satu orang pelanggan. Dalam menentukan ongkos kirim masih dilakukan secara manual dengan menghitung sesuai alamat kirim. Serta dalam pembuatan pelaporan penjualan masih menggunakan catatan penjualan dari nota pembelian yang disimpan. Sehingga menimbulkan resiko kehilangan atau kerusakan nota penjualan.

Berdasarkan permasalahan tersebut maka akan dikembangkan sebuah aplikasi toko online berbasis android. Dengan adanya aplikasi toko online ini dapat memenuhi kebutuhan bisnis ENS Shop dalam hal pengelolaan pemesanan, pengecekan ongkos kirim, dan pembuatan laporan transaksi penjualan yang berisi data penjualan dan omset penjualan bagi pemilik. Untuk selanjutnya dalam penyusunan skripsi ini peneliti mengambil judul "Aplikasi Toko Online Ens Shop Berbasis Android Menggunakan Metode Cross Selling".

\section{METODE PENELITIAN}

\subsection{Metode Observasi}

Teknik observasi adalah teknik pengumpulan data dengan cara peneliti melakukan pengamatan secara langsung di lapangan. Pengamatat disebut observer yang diamati disebut observer.Metode observasi merupakan metode pengumpul data yang dilakukan dengan cara mengamati dan mencatat secara sistematik gejala-gejala yang diselidiki (Supardi, 2006).

\subsection{Teknik Kuesioner}

Angket atau kuesioner merupakan suatu teknik pengumpulan data secara tidak langsung (peneliti tidak langsung bertanya jawab dengan responden). Instrumen atau alat pengumpulan datanya juga disebut angket berisi sejumlah pertanyaan-pertanyaan yang harus dijawab atau direspon oleh responden (Sutopo, 2006). Responden mempunyai kebebasan untuk memberikan jawaban atau respon sesuai dengan persepsinya.

\subsection{Metode Wawancara}

Metode wawancara adalah proses tanya jawab dalam penelitian yang berlangsung secara lisan dalam mana dua orang atau lebih bertatap muka mendengarkan secara langsung informasi-informasi atau keterangan-keterangan (Supardi, 2006). 


\subsection{Diagram Konteks sistem}

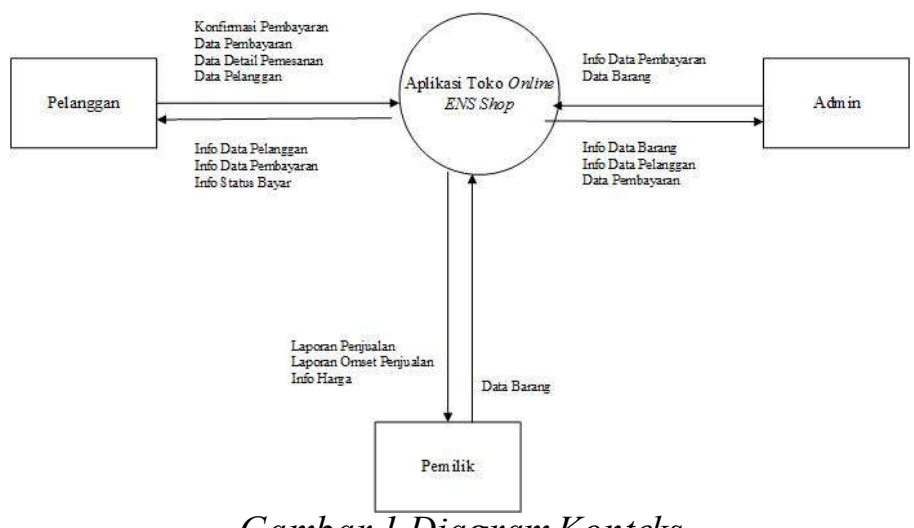

Gambar 1 Diagram Konteks

Diagram konteks pada Gambar 1 menunjukkan bahwa Aplikasi Penjualan ENS Shop ini mempunyai tiga entitas yaitu pemilik, pelanggan dan admin. Entitas pelanggan mempunyai wewenang untuk melakukan input data pelanggan, data detail pemesanan, konfirmasi pembayaran, dan data pembayaran. Kemudian Pelanggan menerima info data pelanggan. Sedangkan admin mempunyai hak akses mengelola data pelanggan dan data barang. Kemudian menerima info data barang, info data pelanggan, data pembayaran. Dan entitas pemilik menginputkan data harga untuk menentukan harga barang dan mendapatkan info data harga, laporan penjualan dan laporan omset perbulan. Relasi Tabel database pada sistem yang dibuat seperti pada Gambar 2.

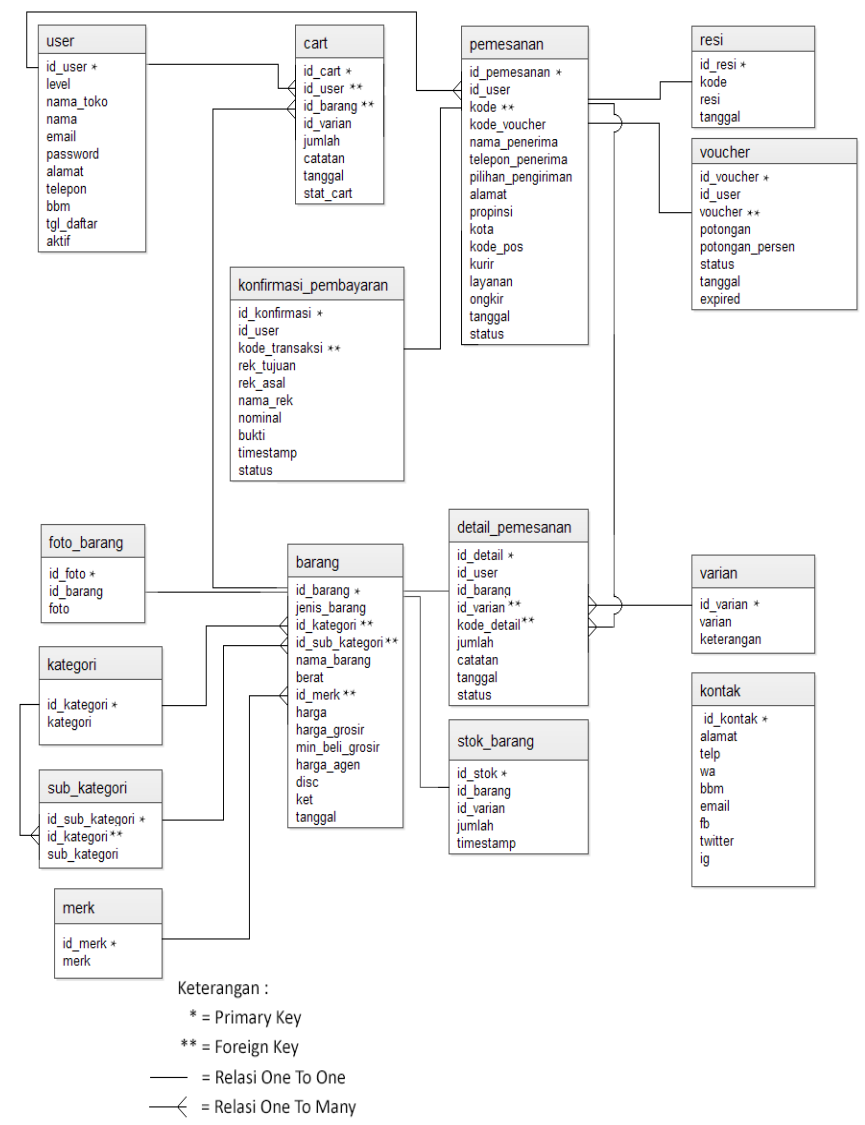

Gambar 2 Relasi Tabel 


\section{HASIL DAN PEMBAHASAN}

\subsection{Halaman Pelanggan}

\subsubsection{Halaman Utama Pelanggan}

Halaman utama terdapat tombol SIGN IN dan DAFTAR. Tombol SIGN IN digunakan untuk masuk ke aplikasi, tombol daftar digunakan untuk mendaftar sebagai pelanggan dengan menginput data pelanggan.

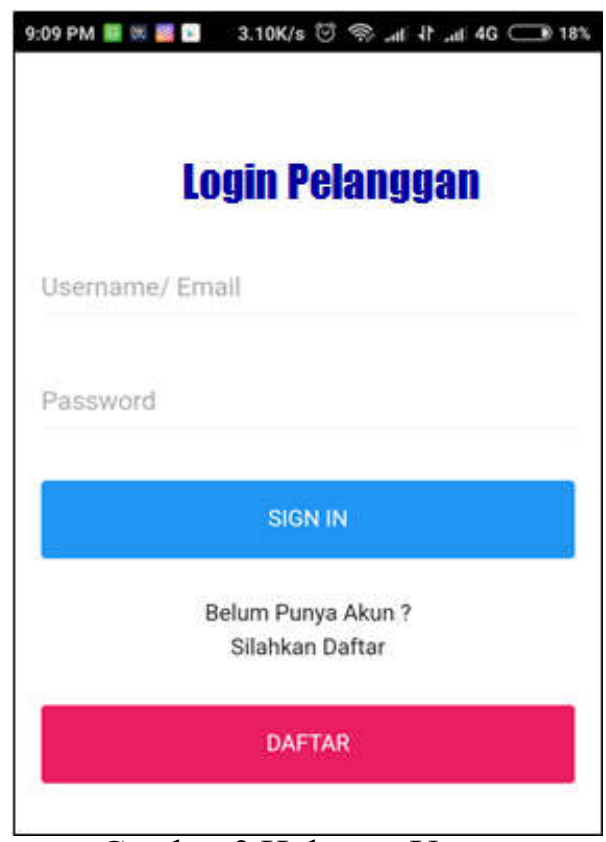

Gambar 3 Halaman Utama

\subsubsection{Halaman Utama Pelanggan Setelah Login}

Setelah pelanggan berhasil Log in, pelanggan memasuki Halaman Utama. Halaman utam pelanggan menampilkan berbagai pruduk yang dijual ENS Shop. Pelanggan juga dapat melihat produk-produk terbaru dari ENS Shop.

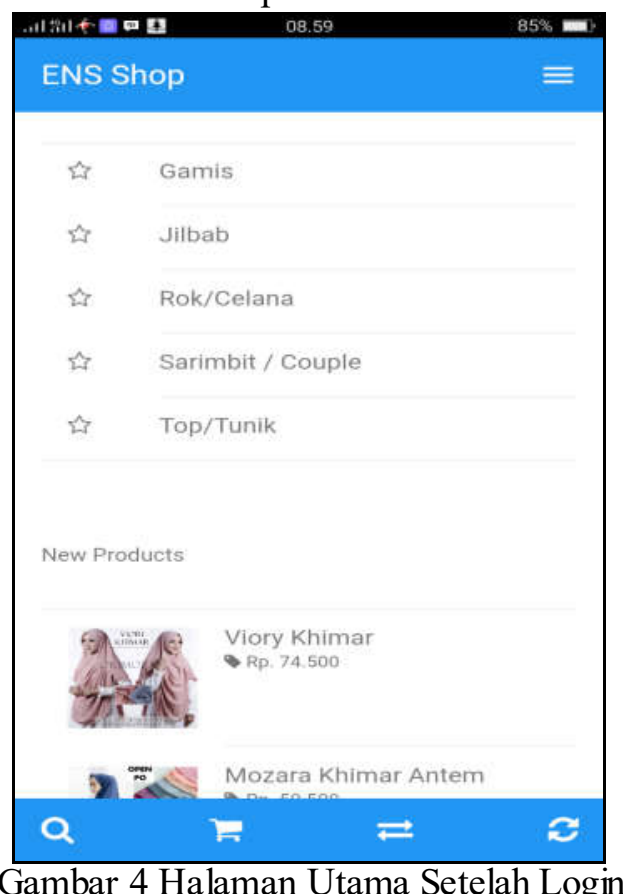




\subsubsection{Halaman Detail Produk}

Pelanggan dapat melakukan pemesanan dengan langkah pertama megklik gambar produk. Kemudian akan tampil detail produk tersebut yang meliputi nama produk, harga, varian, dan material produk.

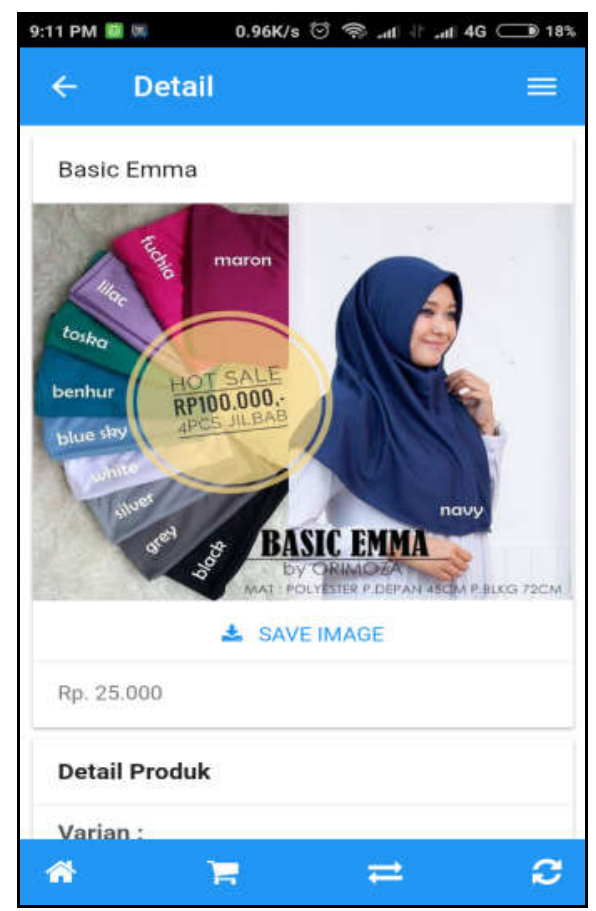

Gambar 5 Halaman Detail Produk

\subsubsection{Halaman Order Produk}

Langkah kedua, pelanggan mengklik Order Produk kemudian muncul form pemesanan. Pelanggan harus mengisi semua data yang dibutuhkan yaitu varian yang dipesan, jumlah yang dipesan, dan catatan tentang ukuran pakaian. Kemudian klik Order Produk. Klik tombol Lanjut Belanja untuk menambah pemesanan produk dan kembali ke menu utama.

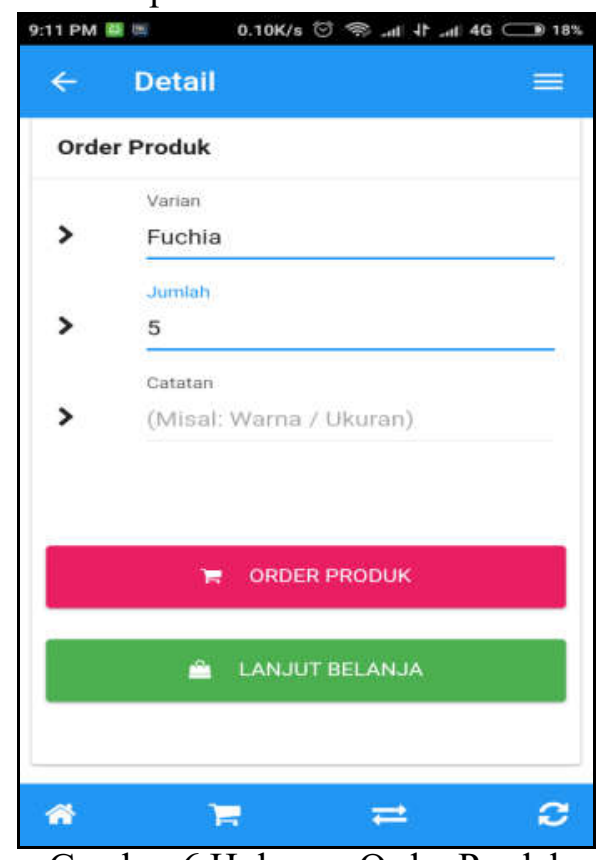

Gambar 6 Halaman Order Produk 


\subsubsection{Halaman Keranjang Belanja}

Langkah ketiga pelanggan mengklik menu Keranjang Belanja untuk melihat barangbarang yang dipesan disertai total harga barang. Pembeli dapat mengisikan data pengiriman produk yaitu pilihan pengiriman, nama penerima, telepon penerima, alamat penerima, jasa pengiriman, dan layanan yang dipilih. Data tersebut berfungsi untuk admin sebagai data pengiriman barang pesanan. Setelah semua diisi maka akan muncul ongkos kirim sesuai alamat dan layanan dari kurir yang dipilih. Kemudian klik lanjut pembayaran. Pelanggan akan mendapatkan informasi mengenai pilihan bank dan nomor rekaning untuk melakukan transfer melalui ATM.

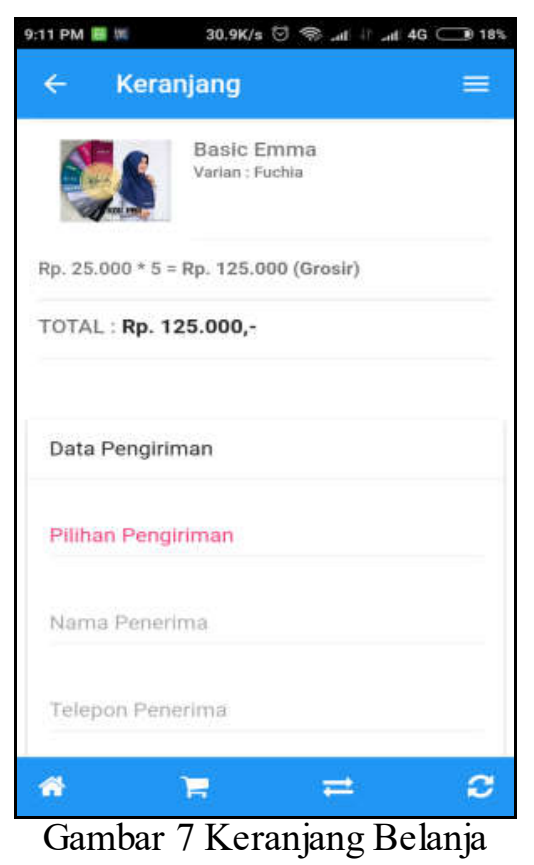

\subsubsection{Halaman Informasi Pembayaran}

Pada halaman ini akan ditampilkan jumlah nominal belanja beserta ongkos kirimnya, dan akan ditampilkan nomor rekening dari ENS Shop untuk melakukan pembayaran melalui transfer bank.

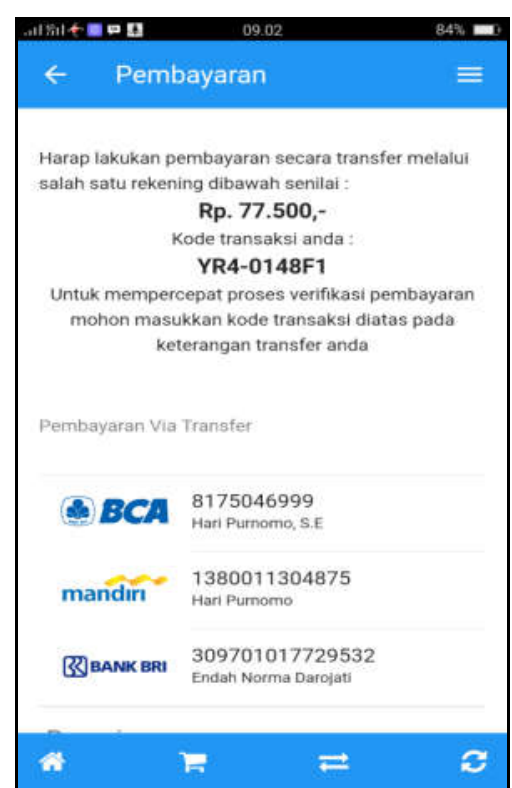

Gambar 8 Halaman Informasi Pembayaran 


\subsubsection{Halaman Konfirmasi Pembayaran}

Setelah user melakukan pembayaran, langkah terakhir, pelanggan melakukan konfirmasi pembayaran pada form pembayaran. form ini berfungsi mengirimkan data pembayaran kepada admin bahwa pelanggan sudah melakukan pembayara. Pelanggan menginputkan Kode Transaksi, Nama Rekening Tujuan, Nama Pengirim, Nomor Rekening dan Nominal Transfer. Kemudian klik Konfirmasi. Kemudian data tersebut disimpan dan diolah oleh admin.

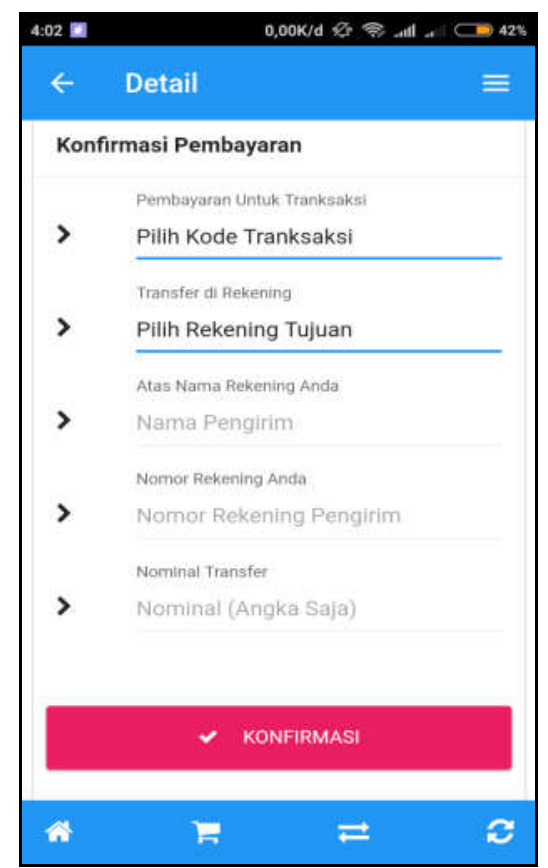

Gambar 9 Halaman Konfirmasi Pembayaran

User yang sudah melakukan konfirmasi pembayaran akan mendapat laporan daftar pemesanan dan mendapatkan Kode Pemesanan, Tanggal Pemesanan, Status Pembayaran, No. Resi, Kurir, dan Layanan Pengiriman.

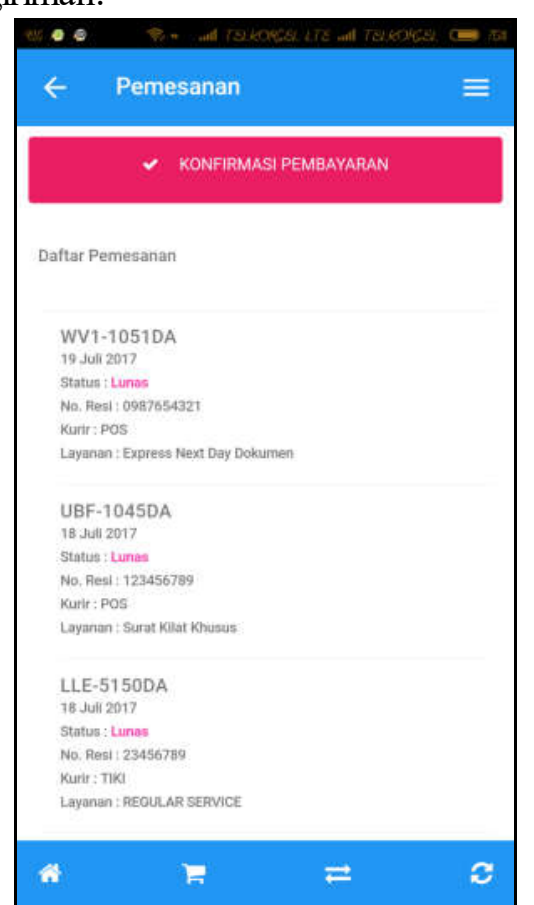

Gambar 10 Halaman Daftar Pemesanan 


\subsection{Halaman Admin}

\subsubsection{Halaman Login Admin}

Langkah pertama admin harus login terlebih dahulu sebelum memasuki halaman Admin dengan menginputkan username dan password kemudian klik Sign in.

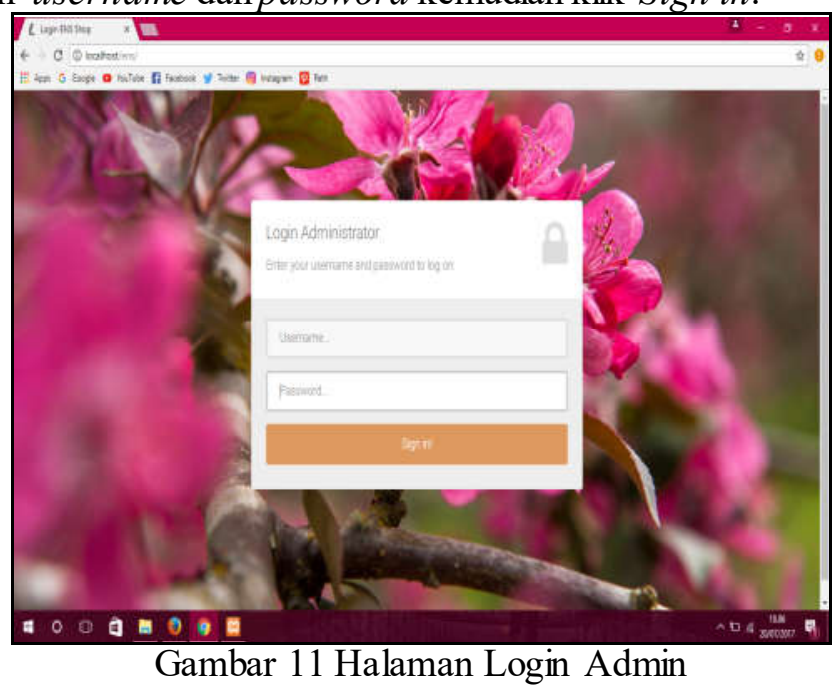

\subsubsection{Halaman Utama Admin}

Setelah admin berhasil login, admin dapat memasuki halaman Beranda. Pada halaman Beranda terdapat menu Beranda, Pengguna, Kategori Barang, Data Barang, Pesanan Masuk, Konfirmasi Pembayaran dan ResiPengiriman.

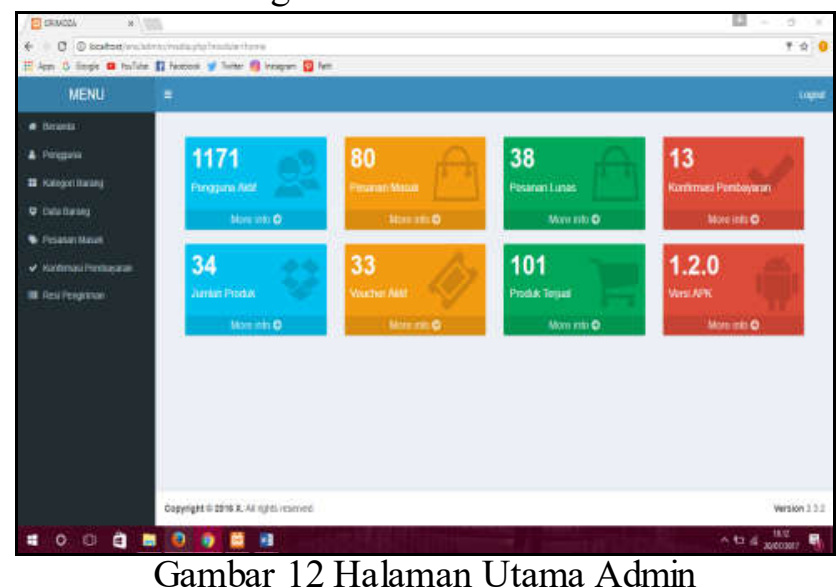

\subsubsection{Halaman Pengguna}

Pada Halaman Pengguna menampilkan daftar pelanggan ENS Shop yang sudah melakukan pendaftaran. Pada form tersebut menampilkan data pelanggan berupa nama, email, nomot telepon, alamat, tanggal pelanggan dan status pelanggan apakah aktif atau tidak. 


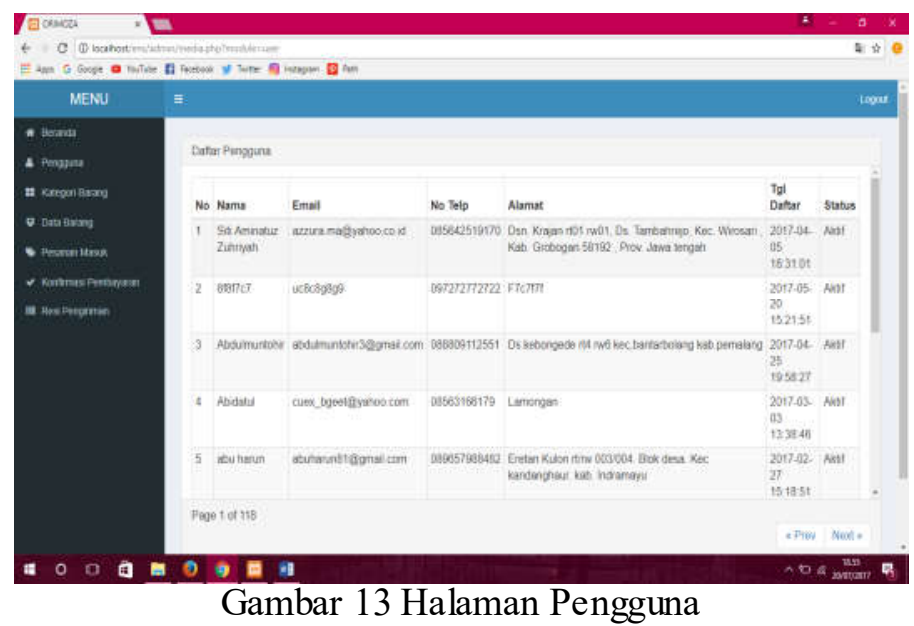

\subsubsection{Halaman Kategori Barang}

Pada halaman Kategori Barang menampilkan daftar kategori barang yang dijual ENS Shop dan admin dapat menambahkan kategori barang apabila terdapat kategori baru.

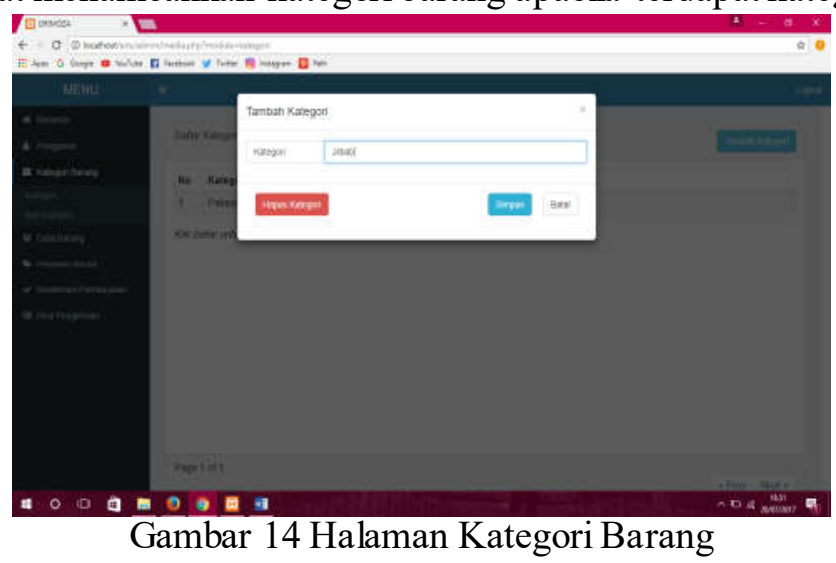

\subsubsection{Halaman Tambah Kategori Barang}

Pada halaman Tambah Kategori, admin dapat melakukan menambah kategori dengan mengisi kolom nama kategori. Data yang perlu diisi yaitu nama kategori barang. Kemudian klik simpan.

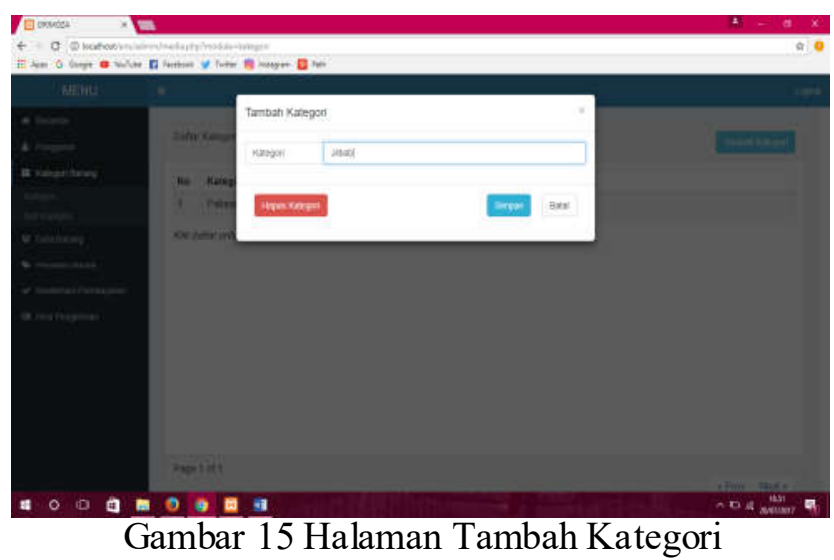

\subsubsection{Halaman Data Produk}

Pada Halaman Data Produk menampilkan data barang yang dijual oleh ENS Shop. Data tersebut meliputi nama produk, harga produk, harga satuan dan berat produk. Pada halaman ini admin dapat melakukan tambah, simpan dan hapus data produk. 


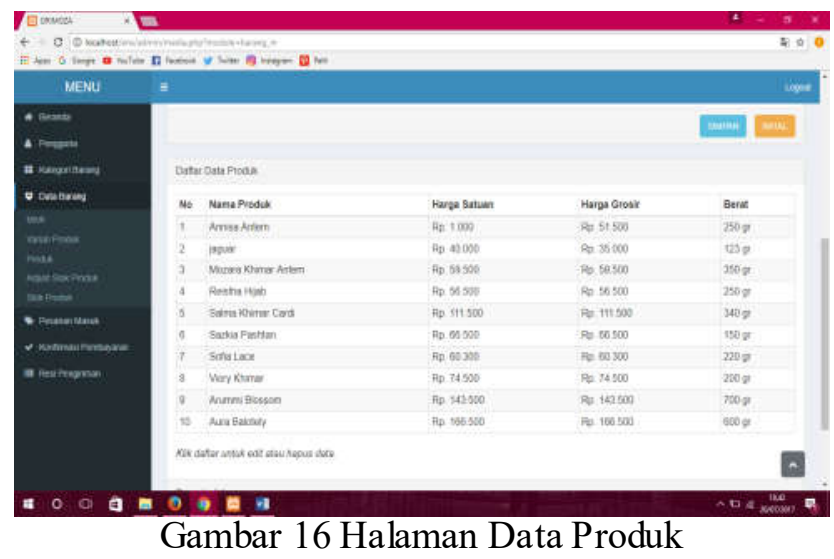

\subsubsection{Halaman Tambah Data Produk}

Pada halaman Data Produk, admin dapat menambahkan data produk yang dijual oleh ENS Shop dengan mengisi form Data Produk meliputi nama kategori, nama produk, merk, barat, harga, keterangan dan upload foto produk kemudian klik simpan.

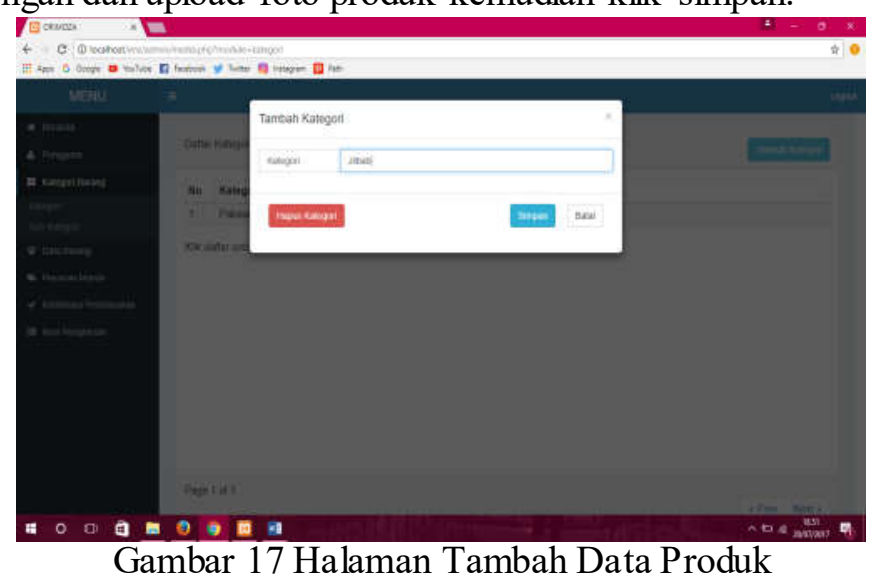

\subsubsection{Halaman Pesanan Masuk}

Langkah selanjutnya admn dapat memeriksa pesanan pelanggan pada menu pesanan masuk. Pada menu pesanan masuk, admin menerima data pesanan meliputi nama pelanggan, kode pemesanan, tanggal pemesanan dan status pemesanan. Pada menu Pesanan Masuk, admin dapat melakukan perubahan status pesanan pelanggan yaitu valid ketika pesanan diterima dan tidak valid apabila pesanan ditolak.

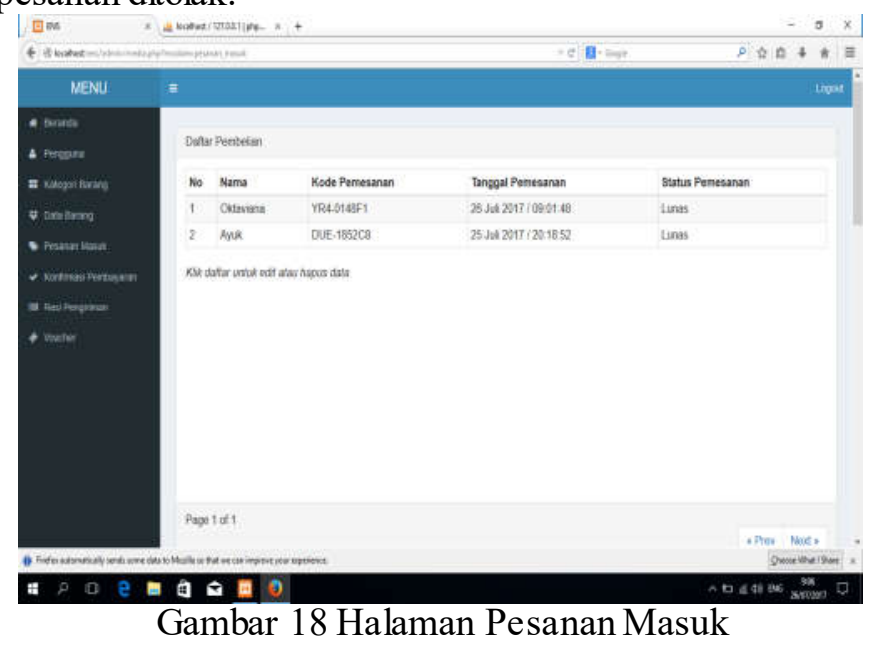

GO INFOTECH: JURNAL ILMIAH STMIKAUB Vol. 26, No. 2, Desember 2020: 143-155 


\subsubsection{Halaman Kofirmasi Pembayaran}

Pada halaman Konfirmasi Pembayaran menampilkan data pembayaran yang dilakukan pelanggan. Data pembayaran menampilkan data Pengirim yaitu data pelanggan yang sudah mentransfer pembayaran melalui rekening ENS Shop. Halaman ini Admin dapat melakukan konfirmasi pembayaran dengan mengganti status pembayaran. Apabila pelanggan sudah mentransfer sesuai pemesanan, maka admin mengubah status menjadi Valid. Kemudian status tersebut diterima oleh Pelanggan sebagai pemberitahuan bahwa Data Konfirmasi Pembayaran sudah diterima oleh Admin.

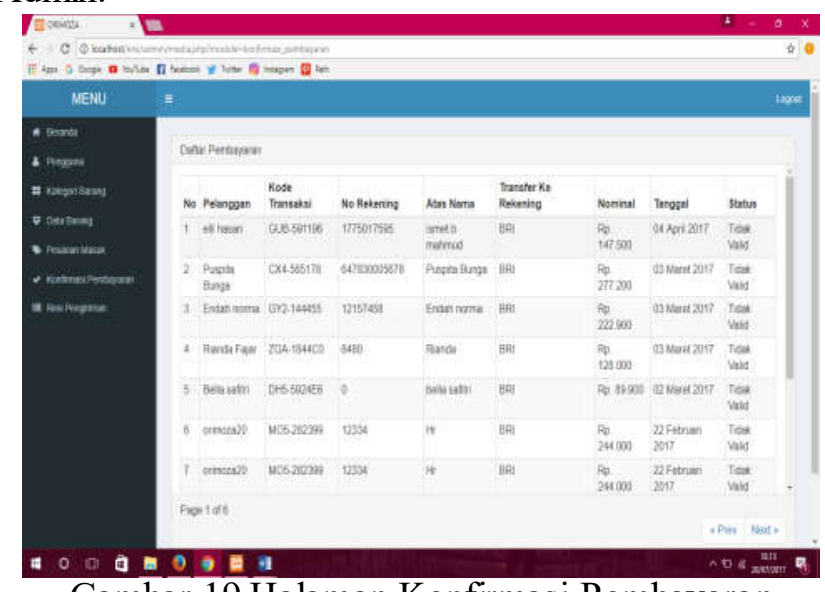

Gambar 19 Halaman Konfirmasi Pembayaran

\subsubsection{Halaman Ubah Status Pembayaran}

Admin mengklik dua kali pada status pembayaran untuk mengganti status pembayaran terhadap pelanggan yang sudah melakukan konfirmasi pemabayaran.

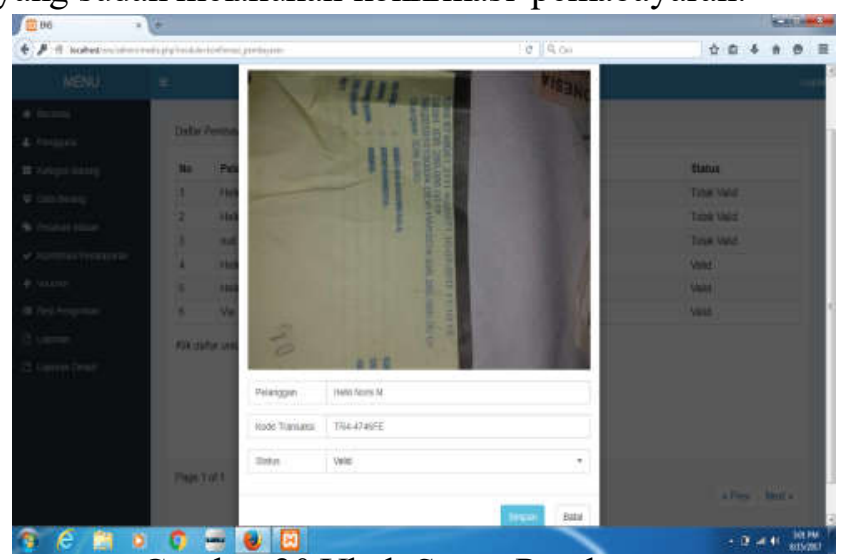

Gambar 20 Ubah Status Pembayaran

\subsubsection{Halaman Resi Pengiriman}

Pada halaman Resi Pengiriman menampilkan nama pelanggan yang disertai kode pelanggan, nomor resi, kurir dan layanan pengiriman. Nomor resi digunakan untuk memantau posisi barang yang dikirim oleh jasa pengiriman barang. 


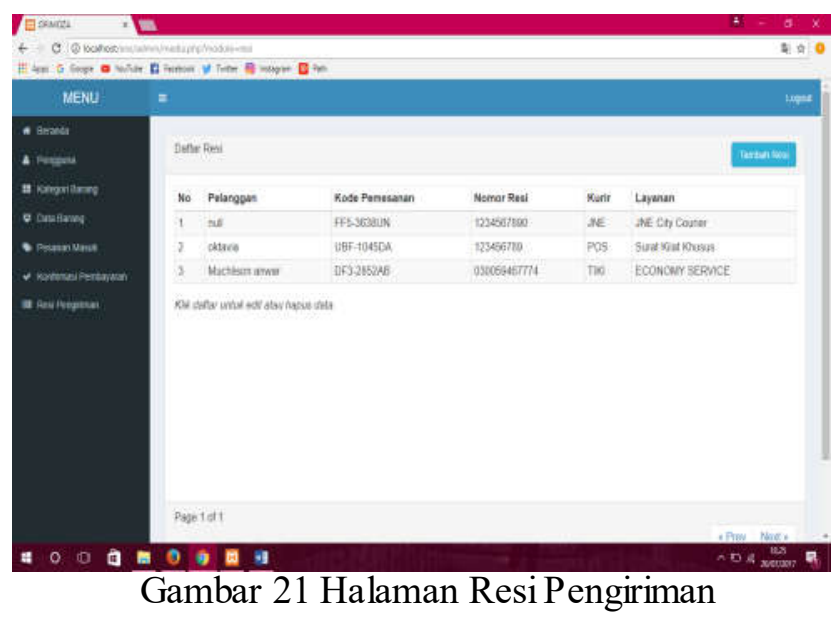

\subsubsection{Halaman Tambah Resi Pengiriman}

Admin dapat melakukan tambah nomor resi apabila ada pembayaran baru dari pelanggan dengan mengklik tombol Tambah Resi. Kemudian muncul form Tambah Resi. Admin menginputkan Nomor Resi sesuai Kode Pemesanan pada textbox Nomor Resi. Kemudian klik tombol Simpan untuk menyimpan perubahan data dan klik tombol Batal untuk membatalkan perubahan data.

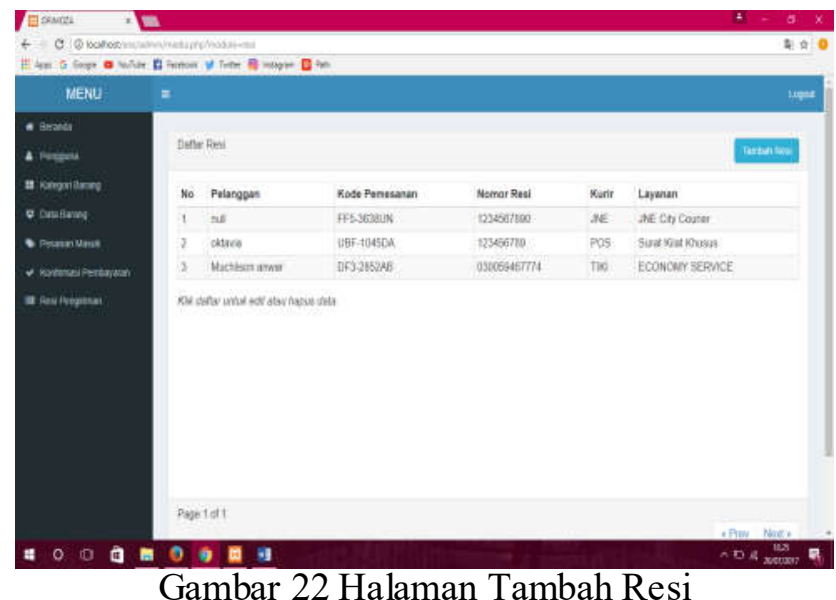

\section{KESIMPULAN}

Rancang bangun aplikasi toko online ENS shop berbasis android menggunakan metode cross selling dapat disimpulkan bahwa:

1. Perancangan dan pembangunan rancang bangun aplikasi toko online ENS shop berbasis android menggunakan metode cross selling dilakukan dengan metode pengembangan sistem waterfall, pemodelan database, pemodelan proses dengan data flow diagram, dan diagram konteks. Sistem dirancang menggunakan bahasa pemrograman JavaScript, menggunakan framework Phonegap dan ApacheCordova, dan database menggunakan MySql. Setelah pengkodean selesai maka dilakukan testing terhadap sistem menggunakan metode blackbox.

2. Aplikasi toko online mampu melakukan proses pemesanan, pengiriman barang dan transaksi pembayaran secara otomatis menghasilkan laporan penjualan bagi pemilik toko online. 


\section{SARAN}

1. Untuk menjaga data-data ataupun sistem ini, sebaiknya dilakukan backup database, setiap selesai menggunakan aplikasi, untuk menghindari kehilangan atau kerusakan pada data.

2. Pengguna sistem disarankan diberi pelatihan terlebih dahulu dalam penggunaan aplikasitoko online ENS Shop berbasis android menggunakan metode Cross Selling, hal ini dimaksudkan supaya pengguna mahir dalam penggunaan aplikasi sehingga prosedur penjualan di toko ENS Shop yang telah ditetapkan oleh pemilik toko dapat berjalan dengan baik.

\section{DAFTAR PUSTAKA}

[1] Dede, Sopandi. 2014. Instalasi dan Konfigurasi Jaringan Komputer. Bandung: Informatika

[2] Petter, Lauster. 2007. Tes Kepribadian (Alih bahasa : D.H Gulo) Edisi Bahasa Indonesia. Jakarta: Bumi Aksara

[3] Pramana, Hengky W. 2011. Aplikasi Inventory Berbasis Access 2003. Jakarta:PT Elex Media Komputindo

[4] Supardi, M.d, (2006). Metodologi Penelitian. Mataram : Yayasan Cerdas Press.

[5] Sutopo, HB. 2006, Metode Penelitian Kualitatif, Surakarta: UNS Press. 